\title{
Onychomycosis - A kórokozók fajspektruma és terápia
}

\section{Onychomycosis - The spectrum of the pathogens and therapy}

\author{
MIHALIK NOÉMI DR., NEMES-NIKODÉM ÉVA, MÁTHÉ MIKLÓS DR., \\ ROZGONYI FERENC DR., KÁRPÁTI SAROLTA DR.
}

Semmelweis Egyetem, Általános Orvostudományi Kar, Bőr-, Nemikórtani és Bőronkológiai Klinika, Budapest, Magyarország

\section{ÖSSZEFOGLALÁS}

Az onychomycosis a népesség 5-20\%-át érintő civilizációs betegség. A körmöt érintő elváltozások több mint 50\%-áért gomba okozta fertőzések felelösek. A szerzók 2006. 07. 01.-2012. 12.31. között a Semmelweis Egyetem Bör-Nemikórtani és Böronkológiai Klinikán onychomycosis miatt kezelt betegek adatait értékelik. 17682 körömmintát vizsgáltak laboratóriumi, mikroszkópos illetve tenyésztéses módszerekkel.

4040 esetben igazolták kórokozó gomba jelenlétét körömbetegségben. A kórokozók meghatározása alapján a kézköröm kaparékokban a sarjadzógombák, a lábköröm kaparékokban a dermatophyton speciesek fordultak eló nagyobb arányban.

\section{Kulcsszavak: \\ onychomycosis - Trichophyton rubrum - sarjadzó gomba - penészgomba}

\section{SUMMARY}

Onychomycosis is considered a ,disease of civilization" affecting approximately 5-20\% of the population. The aim of this study was to evaluate the percentage of cases of onychomycosis caused by each pathogenic group according to the microscopic examination and cultures in a study period of 1st, July 2006. - 31st, December 2012. at the Department of Dermatology, Venerology and Dermatooncology, Semmelweis University, Budapest. Pathogenic role of fungi was detected in 4040/17682 samples. According to our results yeasts were the most common pathogens in fingernail samples, in contrast to toenails, where dermatophytons were more frequent.

\section{Key words: \\ onychomycosis - Trichophyton rubrum - yeast, mould}

Az onychomycosis (Tinea unguium) gyakoriságának köszönhetően a bőrgyógyászat egyik kiemelt fontosságú területe. Egyes felmérések szerint a körömeltérések több mint feléért gombafertôzések felelősek (1). Az onychomycosis nem csupán kozmetikai probléma, diszkomfort érzés mellett súlyos esetben bakteriális felülfertőződés (erysipelas, cellulitis, phlegmone) rizikóját is fokozza (2). Onychomycosis kialakulására hajlamosít az idősebb életkor, gyakori nedves környezet (úszás, házimunka), elégtelen lábhigiéne, mikózis pedis és interdigitális mikózis, psoriasis, diabetes mellitus, immunfunkció romlással járó állapotok és genetikai tényezők szerepét is igazolták a hátterében. Egyes szerzốk szerint a mikózis pedis kezelésével az onychomycosis kialakulása megelőzhetô, míg mások a mikózis pedis és onychomycosis külön etiológiájára hívják fel a figyelmet (3-5). Klinikai kép alapján megkülönböztetünk distalis-lateralis subungualis onycomycosist (DLSO), proximalis subungualis onychomycosist (PSO), fehér superficialis onychomycosist (FSO) és totális dystróphiás onychomycosist (TDO). Egyszerre több lábköröm vagy kézköröm is érintett lehet. Jellemző a körömlemez sárgás-barna elszíneződése, megvastagodása, letöredezése, a köröm alatt morzsalékony massza jelenléte. A lábkörmökön dermatophytonok, a kézkörmökön sarjadzó gombák fordulnak elő gyakrabban. A DLSO és PSO formákban a Trichophyton rubrum, a FSO formában a $T$. mentagrophytes fajok a legvalószínúbb kórokozók $(6,7)$. A diagnózist a klinikai kép mellett a kórokozó gomba azonosítása (mikroszkópos vizsgálat, tenyésztés) jelenti.

A szerzók retrospektív módon elemzik és foglalják össze a Semmelweis Egyetem Bőr-, Nemikórtani és Bőronkológiai Klinikán onychomycosis miatt vizsgált és kezelt betegek körömkaparék mintáiból igazolt gombafertőzések kórokozóinak eloszlási gyakoriságát 2006. július 1. és 2012. december 31. közötti időperiódusban.

\section{Módszerek}

Mintavétel: Anamnézis felvétel, fizikális vizsgálat és a kezeletlen beteg köröm alkoholos tisztítása után körömkaparék illetve törmelék nyerése történt steril tárgylemezre. 
Laboratóriumi diagnózis: A mintákban a gombaelemeket a körömkaparékok 20\%-os $\mathrm{KOH}$ oldatos elókezelése után fénymikroszkópban 400-600-szoros nagyításban értékeltük. A tenyésztés Sabouraud chloramphenicollal és Sabouraud cycloheximiddel kiegészített agarokon történt szobahőmérsékleten 2 héten keresztül. Identifikálás: A gomba faj meghatározása elsősorban a tenyészet makroszkópos vizsgálata alapján történt a telepek színe, formája, felszíni morfológiája, pigmentje alapján. A mikroszkópos vizsgálathoz a tenyészet felszínéról laktofenolgyapotkék celluxlenyomatot készítettünk és fénymikroszkópban 400-600-szoros nagyításban vizsgáltuk. A gombaspeciesek határozása a dermatophytonok elsődleges határozójegyei (makro és mikrokonídiumok, chlamydosporák) és járulékos bélyegei alapján (spirál, karácsonyfa, csomósszerv, rakett hifa), egyéb fonalas gombák esetében konídiumtartók, fialidok, konídiumok elrendeződése, mérete alapján történt.

\section{Eredmények}

2006. 07. 01.-2012. 12. 31. között a beérkezett 17682 mintából 4040 minta esetén igazoltuk kórokozó gomba jelenlétét (22,84\%). A minták 54,15\%-a nőbetegtől, 45,85\%a férfi betegtől származott. A vizsgálatra érkezett betegek átlagéletkora nôk esetén 47,9 év, férfiak esetén 54,5 év volt. 1264/4040 esetben kézkörömből, 2776/4040 esetben lábkörömból történt a mintavétel. A mikroszkópos vizsgálat és/vagy tenyésztések során dermatophytonok, sarjadzógombák és penészgombák kórokozó szerepe is igazolásra került. 52,5\%-ban sarjadzógomba, 41,66\%-ban dermatophyton species, 5,84\%-ban penészgomba tenyészett ki a vizsgálati anyagokból.

A kézköröm kaparékokból sarjadzó gomba tenyészett legnagyobb arányban $(87,1 \%)$ (1. ábra), dermatophyton gomba 7,36\%-ban volt kimutatható. A dermatophytonok közül 97,8\%-ban T. rubrum, 1,1-1,1\% -ban T. interdigitale és $M$. gypseum tenyészett. $M$. gypseum csak a kézen volt kimutatható. Penészgombák közül csaknem kizárólag Aspergillus niger (97,4\%), valamint 2,86\%-ban Scopulariopsis brevicularis tenyészett.

A lábköröm kaparékokban a dermatophyton speciesek fordultak elő legnagyobb arányban $(57,17 \%)$ (2., 3. ábra). A dermatophytonok közül a T. rubrum volt a leggyakoribb (92\%), de T. interdigitale (4,52\%), T. mentagrophytes $(2,7 \%), \quad$ T. tonsurans $(0,62 \%)$, Microsporum canis

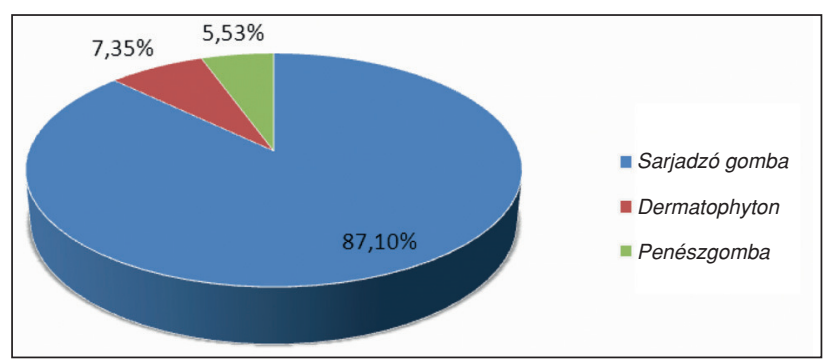

1. ábra

Kórokozó gombák előfordulási gyakorisága kézköröm kaparékokban

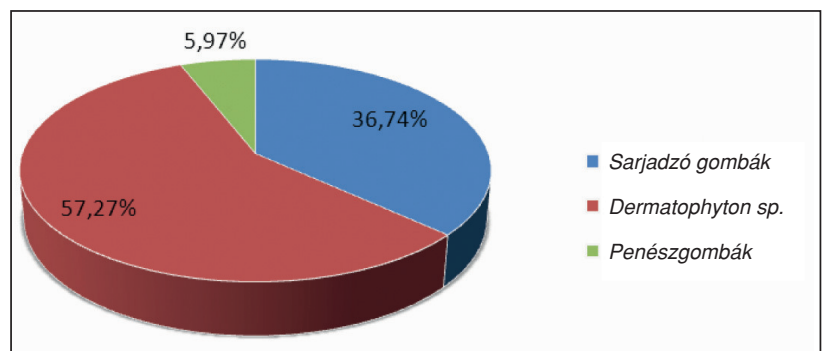

2. ábra

Kórokozó gombák előfordulási gyakorisága lábköröm kaparékokban

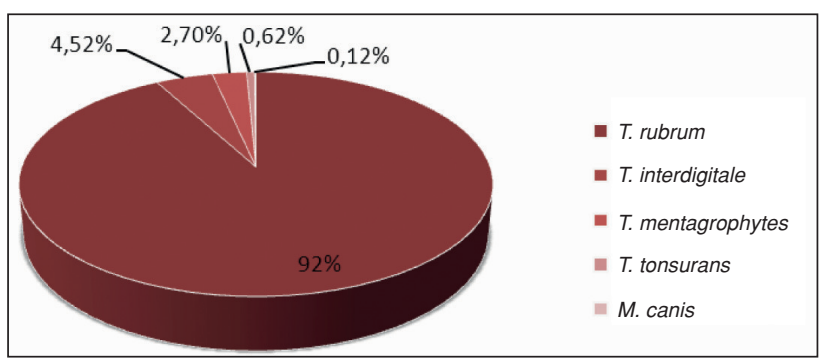

3. ábra

A dermatophyton gombák faj szerinti eloszlása a lábköröm kaparékokban

$(0,12 \%)$ is előfordultak. T. mentagrophytes, T. tonsurans és $M$. canis csak a lábról vett mintákban volt kimutatható. A pozitív lábköröm kaparékok 36,74\%-a sarjadzógomba

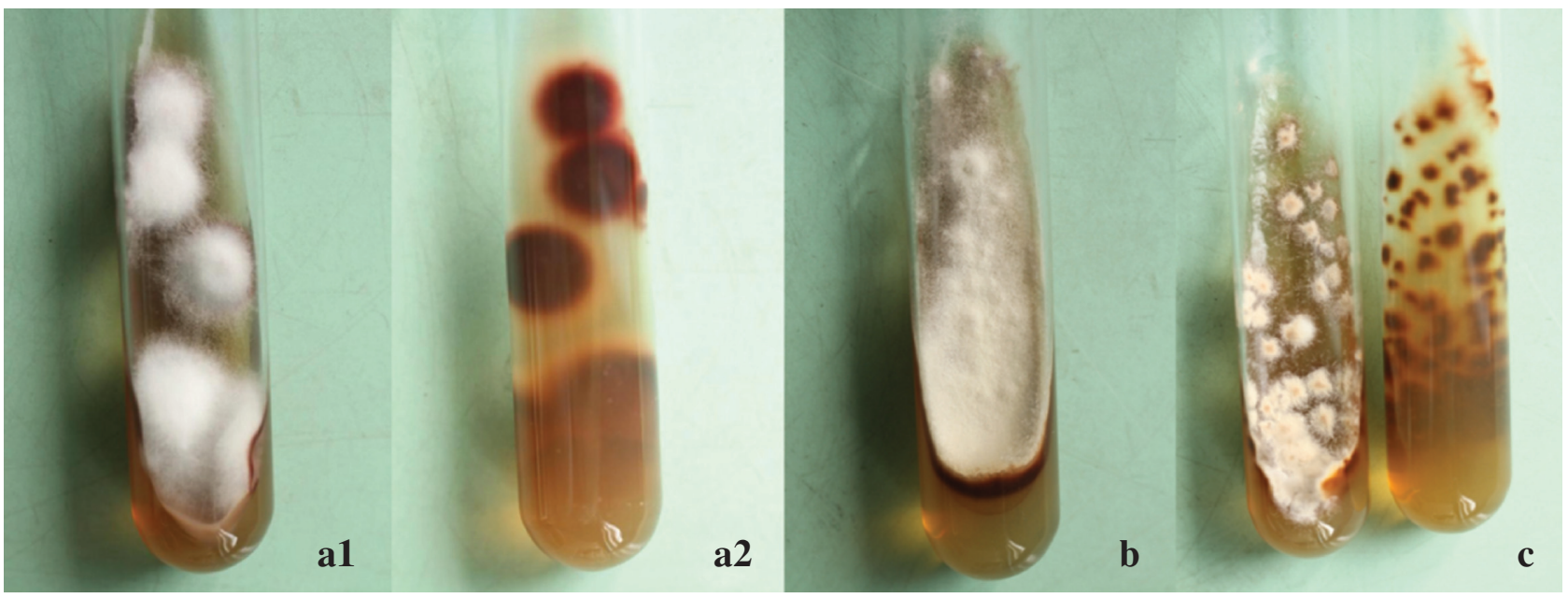

4. ábra

A körömkaparékokban előforduló dermatophyton gombák tenyészetei Sabouroud agaron a1, a2: T. rubrum, $b:$ T. mentagrophytes, $c:$ T. tonsurans 


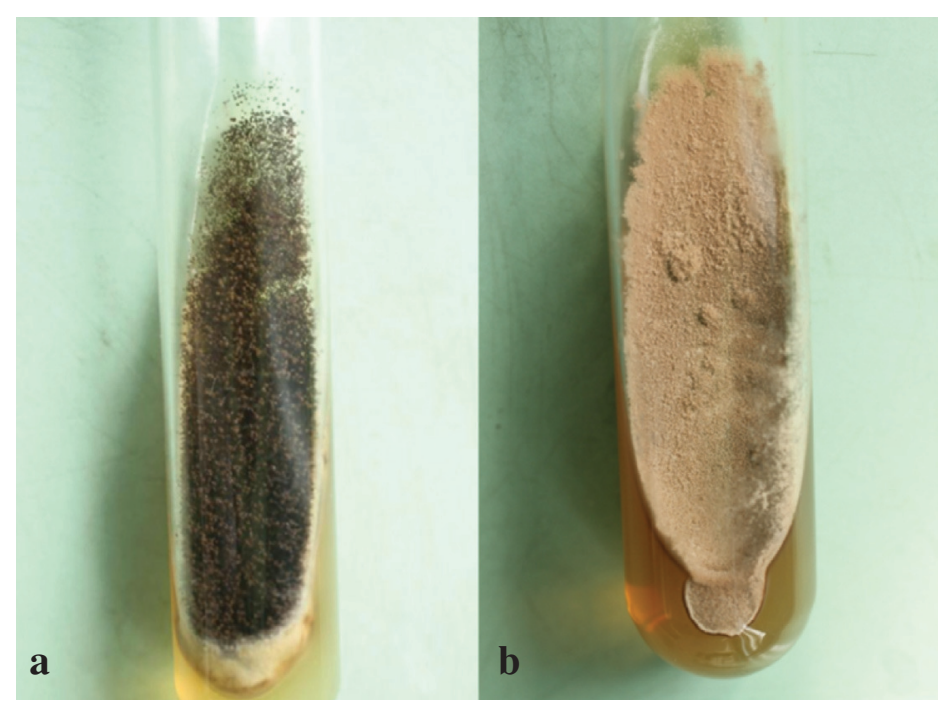

5. ábra

A körömkaparékokban előforduló penészgombák tenyészetei Sabouroud agaron $a$ : A. niger, $b: S$. brevicularis

kóroki szerepét mutatta (4. ábra). A lábköröm kaparékok 5,97\%-ából penészgomba tenyészett: 54,8\%-ban Aspergillus niger, 45,2\%-ban Scopuliaropsis brevicularis fertőzés igazolódott (5. ábra).

\section{Megbeszélés}

Az onychomycosis diagnózisát a klinikai kép és a mikrobiológiai eredmény alapján lehet felállítani. Tenyésztés mellett a mikroszkópos vizsgálat is része a laboratóriumi vizsgálatnak, mert a számos esetben negatív tenyésztési eredmény mellett a mikroszkópos vizsgálat pozitivitása vezet diagnózishoz. (8) A hagyományos diagnosztikai módszerek mellett rendkívül hasznos vizsgálat a PCR technika is, amely magas szenzitivitásával segíti a diagnózist, valamint magas negatív prediktív értéke is van (9).

Egy mikroorganizmus jelenlétének kimutatása a mintából ugyanakkor nem jelenti minden esetben kórokozó szerep betöltését az onychomycosis hátterében. Legtöbb esetben az onychomycosis diagnózisa kimondható, ha dermatophyton tenyészik ki a mintából. Sarjadzó- vagy penészgomba pozitivitás esetén a klinikai kép a meghatározó.

Problémát jelent az onychomycosis kórokozójának meghatározásában, ha a beteg a mintavétel előtt valamilyen szisztémás vagy helyi antimykotikum (lakk) kezelést alkalmazott, ami számos fals-negatív eredményhez vezethet. Ilyen esetben javasolt a mintavétel megismétlése.

A köröm növekedésének üteme a patogenezis egyik fontos tényezője. A kézkörmök növekedése 3-4 mm/hónap, a lábkörmöké 1-2 mm/hónap. Az onychomycosis a lábkörmöket 5-6-szor gyakrabban érinti (vizsgálatunkban a pozitív minták 68,71\%-a), ami a lassabb növekedésnek, az interdigitális régió nedvesebb voltának valamint a talpat érô mechanikai hatásnak köszönhetô.

A körmöt érintő elváltozások gyakoribbak a felnôtt, idősödő populációban. Az életkor előrehaladásával a körömlemez vastagodik, keményebbé válik és a növekedési ütem lassul, a patogén gombákkal való expozíció időtarta- ma növekszik. A vizsgálati idôszak alatt a körömkaparékok 22,84\%-ában igazoltuk kórokozó gomba jelenlétét, melyből több mint $54 \%$ nóbetegtôl származott. Alvarez és mtsai. már leírták, hogy a betegség sokkal gyakoribb nôkben, ami feltételezhetően a nők gyakoribb orvoshoz fordulásának köszönhető (10).

A dermatophyton törzsek onychomycosisban betöltött kórokozó szerepe nem kétséges, Magyarországon a lábkörmökön kialakuló kórkép etiológiáját figyelembe véve a leggyakoribb $(57,27 \%)$ (1113). Az onychomycosis hátterében világszerte vezető helyen áll a Trichophyton rubrum, amely igaz a vizsgálati csoportunkra is (92\%). Számos irodalmi adat utal az Epidermophyton floccosum kórokozó szerepére is, de ez a kórokozó a vizsgálatunk időtartama alatt nem került kimutatásra (14).

A penészgombák előfordulása az onychomycosisban kevésbé gyakori. Számos szaprofita penészgomba a transiens flóra tagja. A mintában kimutatott penész ezen kívül laboratóriumi kontaminációnak is tekinthetô. A penészgombák kórokozó szerepét igazolja azonban, hogy egyes fajok keratináz és proteáz enzimeket termelnek súlyos szerkezeti deffektust okozva a körmökön (15). A penészgombák közül egy német és egy iráni tanulmánnyal ellentétben a vizsgált magyar betegpopulációban az Aspergillus niger (97,14\% kézkörömben, 54,8\% lábkörömben) volt a leggyakoribb kórokozó $(16,17)$.

A körmök kevert fertôzése is gyakran leírt jelenség, főleg a kézkörmök érintettsége esetén jellemzô. A dermatophytonok Candida albicans-sal való társfertőzése ritka, sokkal gyakoribb a T. rubrum és $C$. parapsilosis együttes előfordulása (18).

A betegséget gyakran alulértékelik, bár progresszióra való hajlama és fertőző volta miatt kezelést igényel. A forgalomban levő szisztémás antimikotikumok az ergosterol képzést gátolják. A leggyakoribbnak tekintett dermatophyton fertőzés esetén a terbinafin választandó 250 mg/nap dózisban (19-22). Lábköröm érintettsége esetén 3-4 hétig, kézköröm érintettség esetén 2 hónapig javasolt a kezelés folytatása. A terbinafin, amelynek fungicid hatása van a dermatophyton gombákra és a C. parapsilosis-ra, további előnye az azol készítményekkel szemben, hogy kevesebb a mellékhatása és a ritkábbak az alkalmazásakor megfigyelt gyógyszerinterakciók $(23,24)$. A terbinafin folyamatos kezelés mellett jó terápiás eredménnyel bír az itraconazol lökéskezelés is: $400 \mathrm{mg} / \mathrm{nap} / 1$ hét itraconazol, majd 3 hét szünet. Lábkörmök fertőzöttsége esetén 3, kézkörmök fertőzöttsége esetén 2 lökés ajánlott. Az onychomycosis kezeléséhez a fluconazole terápia (150-300 $\mathrm{mg} /$ hét) is hozzátartozik, amit a teljes gyógyulás eléréséig, azaz a körmök lenövéséig kell alkalmazni, de eredményessége nem közelíti meg a terbinafine-ét $(25,26)$.

$S$. brevicularis vagy $A$. niger okozta patogén penész esetén a terbinafin nem eredményes, ilyenkor az itraconazoltól várható siker.

A sarjadzó gombák identifikálása a vizsgálat során nem történt meg, tekintettel arra, hogy a leggyakrabban 
kitenyésző $C$. albicans és $C$. parapsilosis fajok által okozott fertózés kezelése megegyezik (per os itraconazol adandó $200 \mathrm{mg} /$ nap dózisban), valamint a fluconazol rezisztens fajok (C. glabrata és $C$. krusei) előfordulása ritka a köröm fertôzésekben. Kézköröm érintettség esetén 6, lábköröm érintettség esetén 12 héten át kell folytatni a kezelést.

A szisztémás kezelést több körmöt érintő és/vagy egész körömlemezt destruáló fertôzéseknél ki kell egészíteni helyi kezeléssel. Ugyanakkor lokális kezelés (antimikotikus ecsetelők, krémek) önmagában általában nem vezet teljes gyógyuláshoz. A terápia kudarca emellett diagnosztikus tévedésnek, a beteg nem megfelelő együttmúködésének, antimicotikum-rezisztenciának és a társbetegségek miatt szedett egyéb gyógyszer - antimikotikum interakciójának köszönhető.

\section{Következtetés}

$\mathrm{Az}$ onychomycosis népbetegség, súlyos egészségügyi probléma szerte a világon (27). Diagnózisához elengedhetetlen a klinikai kép helyes értelmezése, direkt mikroszkópos vizsgálat és tenyésztés elvégzése. Mivel a kórokozó gombák spektruma folyamatosan változik, fontosak az epidemiológiai felmérések. Az egyre bővülő rezisztencia viszonyoknak köszönhetően a helyes kezelés megválasztásához nélkülözhetetlen a kórokozó gomba identifikálása. A Semmelweis Egyetem Bőr- Nemikórtani és Bőronkológiai Klinikán kezelt onychomycosisok összefoglalása késôbbi kutatások szempontjából referencia adatbázisnak tekinthető, a kórokozó gombák fajspektrumának ismerete szükséges a preventív és oktató célú munkához.

\section{IRODALOM}

1. Faergemann J., Baran R.: Epidemiology, clinical presentation and diagnosis of onychomycosis. Br J Dermatol. (2003) Sep, 149 Suppl 65, 1-4.

2. Roujeau J. C., Sigurgeirsson B., Korting H. C., Kerl H., Paul C.: Chronic dermatomycoses of the foot as risk factors for acute bacterial cellulitis of the leg: a case-control study. Dermatology. (2004) 209(4), 301-7.

3. Takehara K., Oe M., Tsunemi Y., Nagase T., Ohashi Y., Iizaka S., Ueki K., Tsukamoto K., Kadowaki T., Sanada H.: Factors associated with presence and severity of toenail onychomycosis in patients with diabetes: a cross-sectional study. Int J Nurs Stud. (2011) Sep;48(9), 1101-8.

4. Faergemann J., Correia O., Nowicki R., Ro B. I.: Genetic predisposition-understanding underlying mechanisms of onychomycosis. J Eur Acad Dermatol Venereol. (2005) Sep;19 Suppl 1, 17-9.

5. Sigurgeirsson B., Steingrimsson $O$.: Risk factors associated with onychomycosis. J Eur Acad Dermatol Venereol. (2004) Jan;18(1), 48-51.

6. Foster K. W., Ghannoum M. A., Elewski B. E.: Epidemiologic surveillance of cutaneous fungal infection in the United States from 1999 to 2002. J Am Acad Dermatol. (2004) May;50(5), 748-52.

7. Ploysangam T., Lucky A. W.: Childhood white superficial onychomycosis caused by Trichophyton rubrum: report of seven cases and review of the literature. J Am Acad Dermatol. (1997) Jan;36(1), 29-32.

8. Yadav S., Saxena A. K., Capoor M. R., Ramesh V.: Comparison of direct microscopic methods using potassium hydroxide, periodic acid Schiff, and calcofluor white with culture in the diagnosis of onychomycosis. Indian J Dermatol Venereol Leprol. (2013) Mar;79(2), 242-3.
9. Chandran N. S., Pan J. Y., Pramono Z. A., Tan H. H., Seow C. $S$.: Complementary role of a polymerase chain reaction test in the diagnosis of onychomycosis. Australas J Dermatol. (2013) Feb 21.

10. Alvarez M. I., González L. A., Castro L. A.: Onychomycosis in Cali, Colombia. Mycopathologia. (2004) Aug;158(2), 181-6.

11. Halmy K., Juhász Á., Bálint Á.: A nem dermatophyton penészgombák előfordulása onychomycosisban / Occurence of non-dermatophytic moulds in onychomycosis Bőrgyógyászati és Venerológiai Szemle (2010) 86(1), 18-21.

12. Dhib I., Fathallah A., Yaacoub A., Zemni R., Gaha R,. Said M. $B$.: Clinical and mycological features of onychomycosis years retrospective study (1986-2007). in central Tunisia: a 22 years retrospective study (1986-2007) Mycoses. 2012 Oct 25. doi: $10.1111 /$ myc. 12016 .

13. Ghannoum M. A. , Hajjeh R. A., Scher R., Konnikov N., Gupta A. K., Summerbell R., Sullivan S., Daniel R., Krusinski P., Fleckman P., Rich P., Odom R., Aly R., Pariser D., Zaiac M., Rebell G., Lesher J., Gerlach B., Ponce-De-Leon G. F., Ghannoum A., Warner J., Isham N., Elewski B.: A large-scale North American study of fungal isolates from nails: the frequency of onychomycosis, fungal distribution, and antifungal susceptibility patterns. J Am Acad Dermatol. (2000) Oct;43(4), 641-8.

14. Tchernev G., Penev P. K. , Nenoff P. , Zisova L. G. , Cardoso J. C., Taneva T., Ginter-Hanselmayer G., Ananiev J., Gulubova M., Hristova R., Nocheva D., Guarneri C., Martino G., Kanazawa $N$.: Onychomycosis: modern diagnostic and treatment approaches. Wien Med Wochenschr. (2013) Jan;163(1-2), 1-12.

15. Yin L. J., Hsu T. H., Jiang S. T: Characterization of acidic protease from Aspergillus niger BCRC 32720. J Agric Food Chem. (2013) Jan;61(3), 662-6. doi: 10.1021/jf3041726.

16. Mügge C., Haustein U. F., Nenoff P.: Causative agents of onychomycosis - a retrospective study. J Dtsch Dermatol Ges. (2006) Mar;4(3), 218-28.

17. Aghamirian M. R., Ghiasian S. A.: Onychomycosis in Iran: epidemiology, causative agents and clinical features. Nihon Ishinkin Gakkai Zasshi. (2010) 51(1), 23-9.

18. Järv H., Naaber P., Kaur S., Eisen M., Silm H.: Toenail onychomycosis in Estonia. Mycoses. (2004) Feb;47(1-2), 57-61.

19. Shemer A.: Update: medical treatment of onychomycosis. Dermatol Ther. (2012) Nov-Dec;25(6), 582-93.

20. Singal A., Khanna D.: Onychomycosis: Diagnosis and management. Indian J Dermatol Venereol Leprol. (2011) NovDec;77(6), 659-72.

21. Yin Z., Xи J., Luo D.: A meta-analysis comparing long-term recurrences of toenail onychomycosis after successful treatment with terbinafine versus itraconazole. J Dermatolog Treat. (2012) Dec;23(6), 449-52.

22. Török I., Simon G., Dobozy A., Farkas B., Mészáros C., Nebenführer L., Szepes E., Tóth E.: Long-term post-treatment follow-up of onychomycosis treated with terbinafine: a multicentre trial. Mycoses. (1998) Jan-Feb;41(1-2), 63-5.

23. Bakos N.: Az onychomycosis előfordulási gyakorisága és kezelésének speciális szempontjai idős korban. Bôrgyógyászati és Venerológiai Szemle. (2005) 81:5, 209-213.

24. Soós Gy.: Az empírikus és célzott antymycotikus kezelés farmakokinetikája In: Az orvosi mikológia gyakorlati kérdései. Golden Book Kiadó 2000.

25. Havu V., Heikkilä H., Kuokkanen K., Nuutinen M., Rantanen T., Saari S., Stubb S., Suhonen R., Turjanmaa K.: A double-blind, randomized study to compare the efficacy and safety of terbinafine (Lamisil) with fluconazole (Diflucan) in the treatment of onychomycosis. Br J Dermatol. (2000) Jan;142(1), 97-102.

26. Salo H., Pekurinen M.: Cost effectiveness of oral terbinafine (Lamisil) compared with oral fluconazole (Diflucan) in the treatment of patients with toenail onychomycosis. Pharmacoeconomics. (2002) 20(5), 319-24.

27. Roseeuw D.: Achilles foot screening project. Preliminary results of patients screened by dermatologists. JEADV (1999), 12S1, 6-9.

Érkezett: 2013. 03. 25.

Közlésre elfogadva: 2013. 05. 25. 